\title{
LIGHT MICROSCOPIC STUDY OF PORELLA PLATYPHYLLA (L.) PFEIFF. CELLS UNDER VARIOUS ABIOTIC STRESS FACTORS
}

\section{Szidónia Sütő \& Marianna Marschall*}

\author{
Eszterházy Károly University, Institute of Biology, \\ Department of Botany and Plant Physiology, H-3300 Eger, Leányka u. 6, Hungary; \\ ${ }^{*}$ E-mail: marschall.marianna@uni-eszterhazy.hu
}

\begin{abstract}
The leaf cells of the extremely desiccation tolerant leafy liverwort, Porella platyphylla can be studied natively by light microscope due to their one-cell layered structure. The effects of various abiotic stress factors can be also monitored at cell level following the rate of plasmolysis, and the changes in the structure of cell organelles (chloroplasts, vacuoles, oil bodies). Furthermore our aim was to test the applicability of different stains (neutral red, toluidine blue, methylene blue, SudanIII) in Porella platyphylla cells under experimental treatments. Natural drying at room temperature (for 1 day, 1 week, '62 years' by checking an old herbarium sample), subsequent rehydration, freezing at -18 and $-80^{\circ} \mathrm{C}$, heat treatment at 40 , 50 and $100^{\circ} \mathrm{C}$ (for 5 and $10 \mathrm{~min}$ ), osmotic and salt stress $(0.5 \mathrm{M} \mathrm{NaCl}, 1 \mathrm{M} \mathrm{KSCN}$, $25 \%$ PEG8000) were applied. In the course of monitoring the various stress factors the use of neutral red (at pH 7.6) staining proved to be the most optimal. In control plants one big cherry coloured vacuole was discovered after staining. The central vacuole fragmented into small pieces, then ruptured after 10 minutes, due to the strongest osmotic treatment (1 M KSCN). At the same time chloroplasts were irreversibly disrupted. The oil bodies proved to be the most resistant structures against the various stress factors. Plants hardened for 5-month-long cold were able to regenerate their cell structure and metabolism within 24 hours after a 1-day natural drying. The 3 different high temperature treatments $\left(40,50,100^{\circ} \mathrm{C}\right)$ resulted in similar changes in the cell structure to those induced by the cold treatments. Tissues were coloured by neutral red before freezing and heat treatments suffered less injury compared with the unstained ones. Light microscopic studies are convenient to monitor the regeneration of the cell structure after stress.
\end{abstract}

Keywords: Porella platyphylla, liverworts, abiotic stress, desiccation, cytological structure, oil bodies 


\section{INTRODUCTION}

Studies have shown that major cytological changes take place in mosses during drying-rewetting cycles (Pressel et al. 2006, Proctor et al. 2007a, b) and that these changes occur on a timescale reflected by the physiological events, although comparable information on the effects of de- and rehydration in liverwort vegetative cells is scarce (Marschall and Proctor 1999). In the same experimental design Pressel et al. 2009 described the physiological effects in six desiccation-tolerant (DT) liverworts and the cytological effects of drying and rewetting in two liverworts and examined parallels with and differences from vascular plants and mosses. In their work ultrastructural changes upon water stress and recovery were observed, using light and electron microscopy. Although some of the DT liverworts are well suited for physiological studies (for example Porella platyphylla), they are unsuitable for proper fixation and embedding for electronmicroscopy and, therefore, for answering the cytological questions posed in this study. Cytological changes associated with drying and rehydration in liverworts closely parallel those in mosses. Dehydration elicits profound cytological changes: fragmentation of the vacuole, and rounding of the chloroplasts and mitochondria, with the thylakoids and cristae remaining undamaged (Pressel et al. 2009). These changes closely parallel those seen in mosses and desiccation-tolerant vascular plants, as photosynthetic activity recovers to unstressed value after $24-48 \mathrm{~h}$. As in mosses, in liverworts de- and rehydration are associated with the de- and repolymerization of the cortical microtubule cytoskeleton.

Liverworts are probably the earliest-diverging group of green land plants. Particularly interesting, liverworts contain unique membrane-bound organelles, the oil bodies. Oil bodies are fundamentally different in both substructure and development from lipid droplets, oleosomes, or sphaerosomes, which are common features throughout land plants (Duckett 1986), especially in storage tissues. Unlike lipid droplets (which lack a bounding membrane), the oil bodies of liverworts are bound by a single unit membrane and contain lipid globules suspended in a carbohydrate matrix (Galatis et al. 1978, Duckett and Ligrone 1995). The unusual chemical components of liverworts are generally considered to be concentrated in the oil bodies (Müller 1906, Suire 1975, Suire et al. 2000) and consist of highly diversified mixtures of terpenoids or 
aromatic constituents (Asakawa 1995) in the lipid globules, fructans and polyols (such as mannitol, sorbitol, and volemitol) in the matrix (Smirnoff 1992, Marschall et al. 1998). There is a great relevance in liverwort taxonomy of observing and typing oil bodies (Kis and Pócs 1997, Sass-Gyarmati 2015). The biogenesis, their detailed constituents, the possible biological function of oil bodies in stress tolerance (i. e. in DT) is still unclear (Gavaudan 1927, Chalaud 1931, Pressel et al. 2009, He et al. 2013). Light microscopic investigations by bryologists have confirmed that (1) oil bodies rapidly disappear from herbarium specimens of most liverworts, (2) some species that grow under xeric conditions lack them altogether, and (3) they are as prominent in submerged aquatics as in highly DT taxa (Pressel et al. 2009). In the dry state, these remain substantially unchanged, but after rewetting, they become flattened and regain their normal morphology only after $48 \mathrm{~h}$. When subjected to unnaturally fast rate of drying, the oil bodies, together with other organelles, disintegrate on rewetting. However, there is considerable variation between species in the length of time that a plant retains its oil bodies after collection (Paton 1999), and this seems to depend on its level of DT (Stewart 1978, Pressel et al. 2009). Retention of the oil bodies is firmly determined by the rate of water loss, which in turn depends on the habitat of the plant. Presumably, the oil bodies may have a crucial role in stress tolerance. The first land plant remains, fossil findings look like recent liverworts, which evolved approximately 760 million years ago (Kenrick and Crane 1997, Wellman et al. 2003, He-Nygrén et al. 2004, Qiu et al. 2006, Rubinstein et al. 2010). The chemical constituents of leafy liverworts' oil bodies seem to protect the plant from the pathogens, herbivores, cold temperature and strong light (Hieronymus 1892) and, in addition, from the excessive UV radiation and the desiccation too (Gavaudan 1927, Chalaud 1931, Pressel et al. 2009). Marschall et al. (1998) and Pressel et al. (2009) provided the first experimental evidence that the oil bodies may have a crucial role in the metabolism of desiccation tolerance by suggesting a shifting of soluble carbohydrates or other moieties into the cytosol. Desiccation caused a decrease in sucrose and total fructan (the major components of the soluble carbohydrate pool of Porella platyphylla) but an increase in the proportion of highmolecular weight fructan, leading the authors to suggest that polymerization occurred during drying. Marschall et al. (1998) further argued that, although the fate of soluble carbohydrates 
during tissue drying was not investigated, some of them appeared to be converted to an insoluble form or to a noncarbohydrate such as terpenoids in the oil bodies and that oil bodies could act as a store of carbon to buffer the soluble carbohydrate pool.

The aim of this study was to provide more information of the cytological changes associated with abiotic stress factors and recovery mechanisms using light microscopy in a desiccation tolerant leafy liverwort (P. platyphylla), focusing particular attention on the behaviour of the oil bodies. The effects of various abiotic stress factors such as natural drying and subsequent rehydration, freezing at -18 and $-80^{\circ} \mathrm{C}$, heat treatment at 40,50 and $100^{\circ} \mathrm{C}$ (for 5 and $10 \mathrm{~min})$, osmotic and salt stress ( $0.5 \mathrm{M} \mathrm{NaCl}, 1 \mathrm{M} \mathrm{KSCN}, 25 \%$ PEG8000) were monitored at cell level following the rate of plasmolysis, and the changes in the structure of cell organelles (chloroplasts, vacuoles, oil bodies). Furthermore our aim was to test the applicability of different stains (neutral red, toluidine blue, methylene blue, Sudan-III) in Porella platyphylla cells, to make more profoundly visible the cytological changes during monitoring the effect of the different abiotic stress factors.

\section{MATERIALS AND METHODS}

\section{Plant material}

Porella platyphylla (L.) Pfeiff. is a DT leafy liverwort and was collected from an area of limestone woodland in the Bükk Mountains, north-east Hungary, near Felsőtárkány village in autumn and winter in 2013. The plant mostly appears in northerly exposed tree-shaded sites, and can usually be found on limestone rocks, but can also appear on tree-trunks. The plants were at their full turgor when they were collected. Until the experiments plants were kept in fully hydrated states (no longer than 3 days) in plastic boxes in a fridge at $5^{\circ} \mathrm{C}$.

\section{Dying techniques}

Different cell stains (neutral red at $\mathrm{pH}$ 2.1, 4.7, and 7.6, toluidine blue, methylene blue, Sudan III) were used to test their applicability in $P$. platyphylla leaves during monitoring the effects of the various abiotic stress factors. 


\section{Experimental treatments}

Natural drying and rehydration

In autumn and winter, freshly collected plants at full turgor were allowed to dry for 1 day in the laboratory at $24{ }^{\circ} \mathrm{C}$, RH $35-40 \%$ and PPFD of $100 \mu \mathrm{mol} \mathrm{m} \mathrm{m}^{-2} \mathrm{~s}^{-1}$. This process resulted in slow drying of the liverworts. After the drying, rehydration was achieved by immersing the plants in distilled water. After remoistening constant hydration status was maintained in glass desiccators containing distilled water. The changes in the cell structure were monitored by light microscopy after $0,10,30,40 \mathrm{~min}, 1 \mathrm{~h}, 24 \mathrm{~h}$ and $48 \mathrm{~h}$ following rehydration.

A 62-year-old herbarium sample of $P$. platyphylla, which was collected at Felsőtárkány in 1953, was remoistened with distilled water, methylene blue and neutral red (at pH 2.1, 4.7, 7.6) stains and the cell structure was studied by light microscopy 0 and 30 min after rehydration.

\section{Cold treatment in dark}

Autumn samples were kept at full turgor in $5^{\circ} \mathrm{C}$ for 5 months in dark. After the cold treatment samples were allowed to dry for 1 day in the laboratory at $24{ }^{\circ} \mathrm{C}, \mathrm{RH} 35-40 \%$ and PPFD of $100 \mu \mathrm{mol} \mathrm{m}^{-2} \mathrm{~s}^{-1}$. After drying, rehydration was achieved by immersing the plants in distilled water. After remoistening constant hydration status was maintained in glass desiccators containing distilled water. The changes in the cell structure were monitored by light microscopy after $0,10,30,40 \mathrm{~min}, 1 \mathrm{~h}, 24 \mathrm{~h}$ and $48 \mathrm{~h}$ following rehydration. In another case, the samples were taken in winter and were then subjected to dehydration for 1 day at laboratory air. Rewetting was carried out with distilled water and monitoring of the cells was done at the same time intervals as in the autumn samples.

\section{Freezing}

The plant samples were frozen at $-18^{\circ} \mathrm{C}$ and $-80^{\circ} \mathrm{C}$ for 5 days. Neutral red staining ( $\mathrm{pH} 7.6$ ) was applied before as well as after the freezing treatment.

\section{Heat treatment}

Unstained and neutral red ( $\mathrm{pH} 7.6$ ) stained plants were subjected to heat treatments at 40,50 and $100^{\circ} \mathrm{C}$ for 5 and $10 \mathrm{~min}$. Heat treatments were carried out in a water-bath. 
Osmotic and salt stress

Neutral red (pH 7.6) stained plants were subjected to the following osmotic and salt stress for 3 hours: 25\% PEG8000 ( $\Psi_{\mathrm{s}}=-1.435$ $\mathrm{MPa}), 0.5 \mathrm{M} \mathrm{NaCl}\left(\Psi_{\mathrm{s}}=-2.318 \mathrm{MPa}\right)$ and $1 \mathrm{M} \mathrm{KSCN}\left(\Psi_{\mathrm{s}} \mathrm{S}=-4.381\right.$ $\mathrm{MPa})$.

\section{Light microscopic studies}

The cells of Porella platyphylla leaves were studied natively by light microscope due to their one-cell layered structure. The cytological changes that resulted from the various abiotic stress factors applied were monitored with an Olympus CX 40 type of light microscope, and the recordings were taken by an Olympus DP12 microscope camera.

\section{RESULTS AND DISCUSSION}

\section{Methylene blue stain}

The cells of Porella platyphylla leaves are uniform. Methylene blue stain coloured the cell walls in the leaf cells of Porella platyphylla at full turgor and the colour of the cytoplasm changed to light blue due to methylene blue linking to objects with acidic character (Photo 1a). Lots of oval chloroplasts and shiny homogeneous oil bodies are visible in turgid cells. Oil bodies in $P$. platyphylla are small, numerous, and not very distinct. Moreover, like many other DT liverworts, P. platyphylla is extremely difficult to infiltrate with resin (Duckett et al. 1988), the improminent oil bodies do not fix and embed well for electron microscopy (Duckett et al. 2006a, 2006b), therefore views we get by light microscopy could be important and valuable.

In the 62-year-old herbarium sample the membrane structure disintegrated, cells could not regenerate upon rehydration. Oil bodies were disrupted, methylene blue stained the remaining parts of chloroplasts structure (Photo $1 b$ ). 

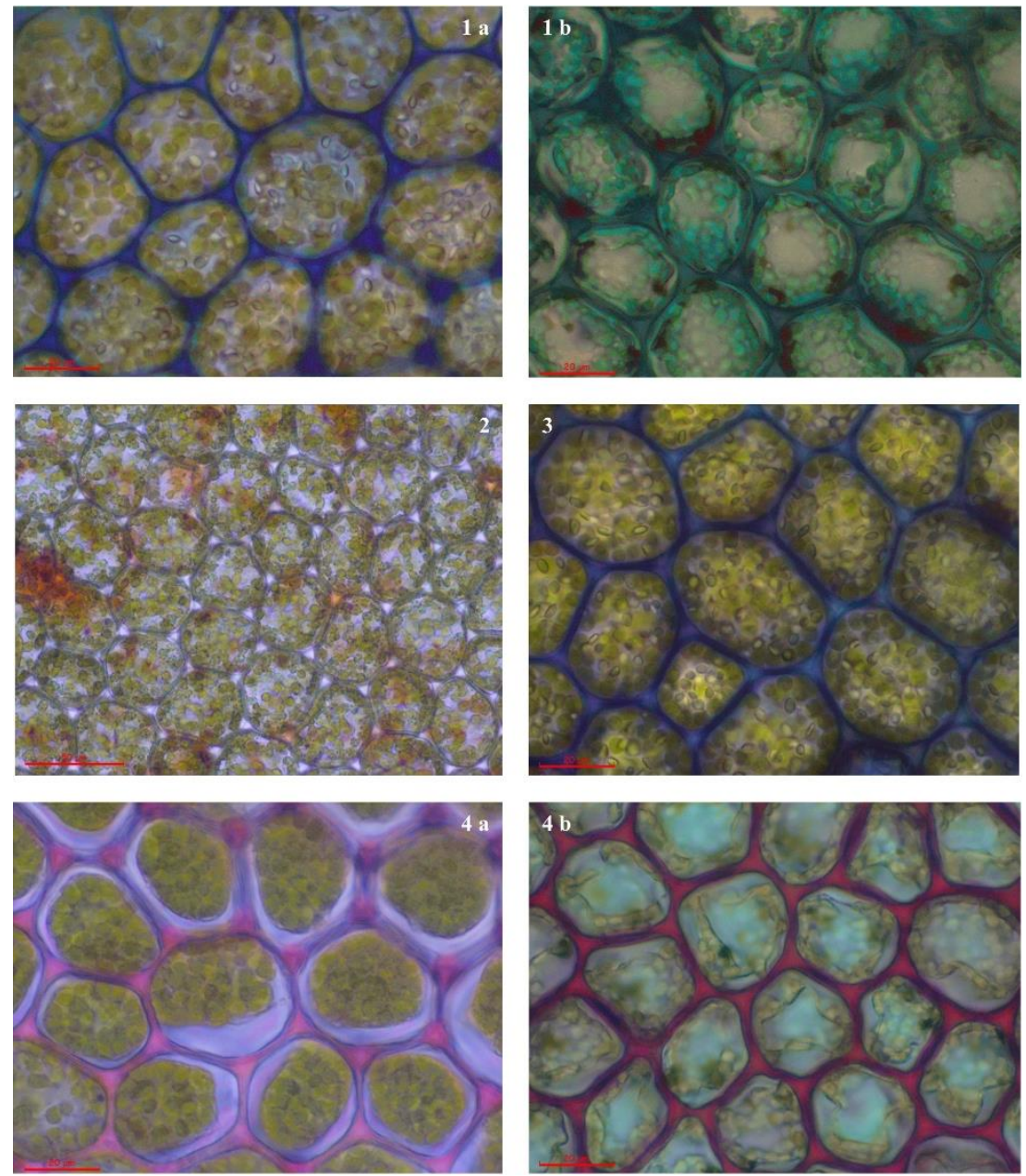

Photo 1a, b. a) Leaf cells of $P$. platyphylla at full turgor stained by methylene blue. b) Dead leaf cells of a 62-year-old (a herbarium sample) P. platyphylla were remoistened and stained by methylene blue. Photo was taken 30 minutes after rehydration. Scale bars $=2 \mu \mathrm{m}$. Photo 2 . The result of applying Sudan III in the leaf cells of $P$. platyphylla at full turgor. Scale bar $=2 \mu \mathrm{m}$. Photo 3. Leaf cells of $P$. platyphylla at full turgor stained by toluidine blue. Scale bars $=2 \mu \mathrm{m}$. Photo $4 \mathbf{a}, \mathbf{b}$. $P$. platyphylla leaf cells a) at full turgor b) in the 62-year-old herbarium sample were stained with neutral red at $\mathrm{pH}$ 2.1. Scale bars $=2 \mu \mathrm{m}$.

\section{Sudan III stain}

The Sudan III stain is widely used for microscopy procedures in plant tissues which have large oil content. Using Sudan III neutral fats (lipids) are coloured red. The reason why we tried this staining 
on P. platyphylla is that we wanted to see whether oil bodies were coloured or not. The method was not suitable for P. platyphylla. The relatively high alcohol content of Sudan III significantly damaged the liverwort cells (Photo 2) and the oil bodies too. On the other hand, it can't be excluded that the oil bodies of P. platyphylla do not contain neutral lipids where the stain could be linked.

\section{Toluidine blue stain}

Applying alcalic aniline stain, the toluidine blue, the cell walls are coloured purple blue and the cytoplasm light violet (Photo 3).

\section{Neutral red staining at different $\mathrm{pH}-\mathrm{s}$}

In P. platyphylla leaf cells at full turgor the cell walls were stained reddish pink with neutral red at $\mathrm{pH}$ 2.1. At this $\mathrm{pH}$ the cells suffered convex plasmolysis, cell membrane separated from the cell wall. Oil bodies could not be observed, and the other organelles were degraded, for example the chloroplasts, their content formed green grist. The vacuoles were not stained (Photo $4 a$ ). The cell walls of a 62 -year-old herbarium leaf sample were also painted reddish pink (Photo 4b).

In P. platyphylla leaf cells at full turgor the cell wall, cytoplasm and vacuoles were coloured dark blue/scarlet with neutral red at $\mathrm{pH}$ 4.7. The membranes and the organelles remained safe and sound after the staining at $\mathrm{pH} 4.7$, so this $\mathrm{pH}$ did not have a destructive effect on the cell structure (Photo 5a) The cell walls and some remaining parts of organelles of the 62-year-old herbarium leaf sample were also painted reddish pink (Photo 5b).

Applying neutral red at $\mathrm{pH} 7.6$ in P. platyphylla leaf cells at full turgor, the vacuoles were coloured red intensively due to the neutral red cationic trapping mechanism, cell walls were not stained (Photo 6a). Using neutral red at $\mathrm{pH} 7.6$ was found to be the most suitable staining for studying the effects of various abiotic stress factors in $P$. platyphylla leaf cells by light microscopy. In the old herbarium leaf sample only the cell walls were coloured light pink (Photo 6b). 

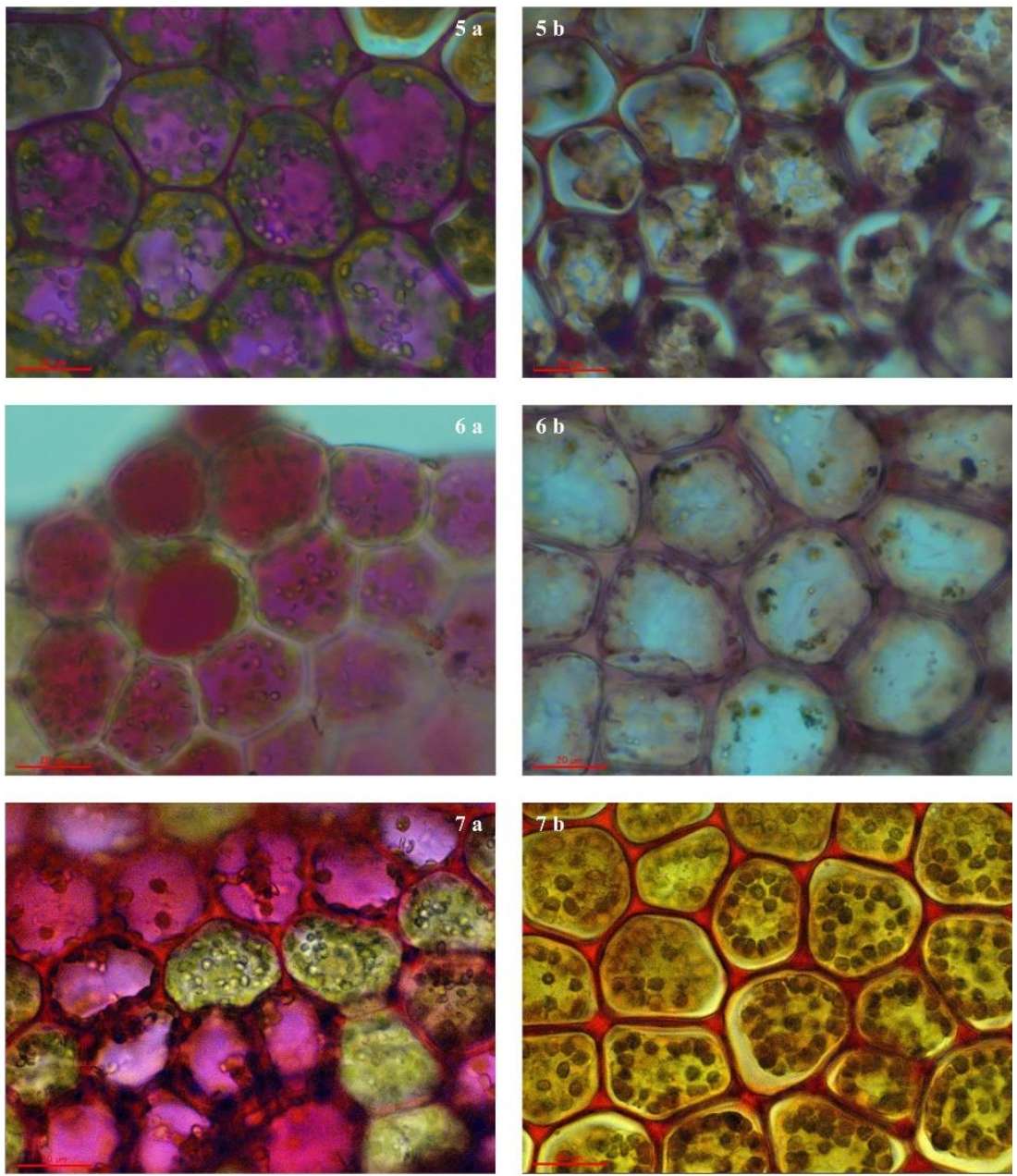

Photo 5a, b. P. platyphylla leaf cells a) at full turgor b) in the 62-year-old herbarium sample were stained with neutral red at $\mathrm{pH}$ 4.7. Scale bars $=2 \mu \mathrm{m}$. Photo 6a, b. $P$. platyphylla leaf cells a) at full turgor b) in the 62-year-old herbarium sample were stained with neutral red at pH 7.6. Scale bars $=2 \mu \mathrm{m}$. Photo 7a, b. P. platyphylla leaf cells at full turgor were frozen at a) $-18^{\circ} \mathrm{C}$ and b) $-80^{\circ} \mathrm{C}$. Before freezing neutral red staining was applied at $\mathrm{pH}$ 7.6. Scale bars $=2 \mu \mathrm{m}$.

\section{The effect of freezing at -18 and $-80^{\circ} \mathrm{C}$}

Before freezing at -18 and $-80^{\circ} \mathrm{C}$ P. platyphylla leaf cells at full turgor were stained with neutral red at $7.6 \mathrm{pH}$. At both freezing temperatures the organelles were damaged and dispersed around in the cytoplasm (Photo $7 a, b)$. Freezing at $-18^{\circ} \mathrm{C}$ resulted in more 
visible damage symptomes in the cell structure than freezing at $-80^{\circ} \mathrm{C}$. The reason for this is that the longer and slower freezing process could cause the formation of large ice crystals which destroy membrane systems and organelles too. Cells were unimpaired after the rapid and short frost effect at $-80^{\circ} \mathrm{C}$. When the cells were coloured with neutral red before freezing, the melting process had less harmful effect on the cell structure. The water vapour is responsible for the destructive effects inside the cells. In many instances the cells are damaged more during the melting process as during the freezing. Staining before freezing could have a protective role during melting. The chloroplasts were visible in their original structural arrangement, but they became a little bit bigger and deformed than in the control samples. Vacuoles could't be observed in the tissues after the treatment.

Applying colouring after the freezing of the Porella samples at $-18^{\circ} \mathrm{C}$, the cells were disintegrated, and the cytoplasm effused. The chloroplasts were damaged; they lost their structure and aggregated near the cell walls, peripherally. The oil bodies were not visible in their original state (Photo 8a).

When we applied staining after the freezing of the P. platyphylla samples at $-80^{\circ} \mathrm{C}$ the cells plasmolyzed, chloroplasts disintegrated and became granulose, but they did not aggregate peripherally, and the cell membrane seemed to be intact (Photo $8 b$ ). The reason why the cell walls were painted with neutral red at $\mathrm{pH} 7.6$ is because membranes, tonoplasts were disrupted upon freezing and the acidic character of vacuole could be released and could alter the $\mathrm{pH}$ of the neutral red stain. The molecular form of the neutral red turned to be positively charged. The cations of the neutral red could adsorb at the negatively charged sites of the cell walls in both freezing treatments (Photo 8a, b). 

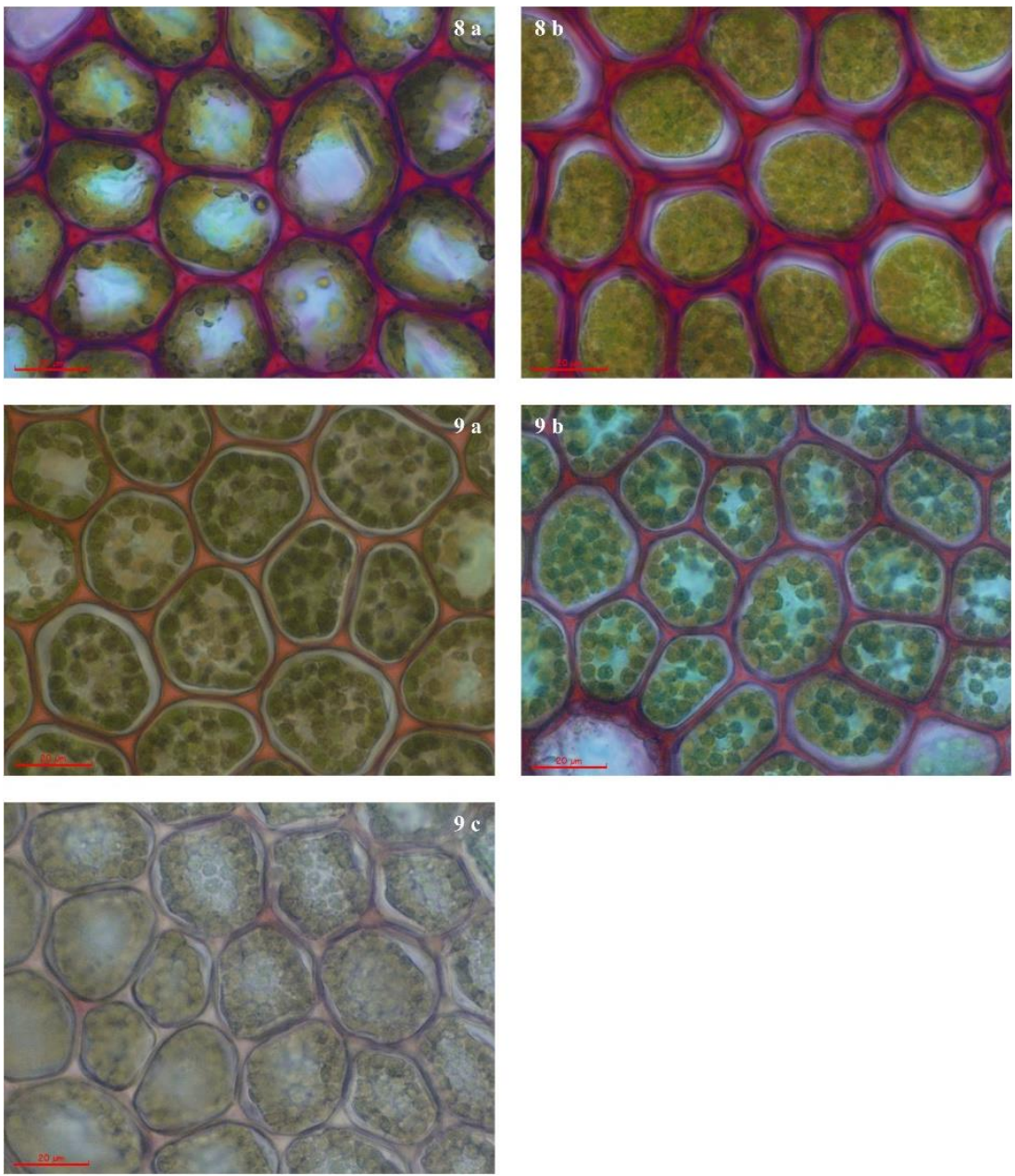

Photo 8a, b. P. platyphylla leaf cells at full turgor were frozen at a) $-18^{\circ} \mathrm{C}$ and b) $-80^{\circ} \mathrm{C}$. After freezing neutral red staining was applied at $\mathrm{pH}$ 7.6. Scale bars $=2 \mu \mathrm{m}$. Photo 9a, b, c. $P$. platyphylla leaf cells at full turgor were heated at a) $40^{\circ} \mathrm{C}$ and b) $50^{\circ} \mathrm{C}$ and c) $100^{\circ} \mathrm{C}$ for 5 minutes. Before heating treatments neutral red staining was applied at $\mathrm{pH}$ 7.6. Scale bars $=2 \mu \mathrm{m}$.

\section{Heat treatment}

Three high-temperature treatments $\left(40,50\right.$ and $\left.100^{\circ} \mathrm{C}\right)$ were applied for 5 and 10 minutes. During the 10 -minute length period of the treatments at 40 or $50^{\circ} \mathrm{C}$, the damage suffered by plant cells was not significantly distinguishable. Heating the Porella leaves at $100^{\circ} \mathrm{C}$ for 5 or 10 minutes did not result in distinct effect either. 
Comparing the unstained and the neutral red stained samples of the cells it was found that the use of neutral red had a moderate protective role against high temperature. After applying the $40^{\circ} \mathrm{C}$ as heat treatment oil bodies were not visible, the chloroplasts were deformed in both the stain-free and the coloured samples. The tonoplasts were injured and the neutral red trapped in the vacuoles until then was released, became charged and the neutral red cations stained the cell walls. In the coloured cells - compared with the unstained ones - a slight rate of plasmolysis was noticed, but the basic cell structure remained unchanged (Photo 9a).

After applying the $50^{\circ} \mathrm{C}$ as heat treatment chloroplasts were strongly damaged and deformed, but their original arrangement remained unchanged, maybe due to the effect of the heat on the cytoskeleton. The plasmolysis was more emphasized than in the $40^{\circ} \mathrm{C}$-treated cells (Photo $9 \mathrm{~b}$ ). After the $100^{\circ} \mathrm{C}$ treatment, the stain was released from the cells, but the cells remained relatively intact. The chloroplasts were deformed and their internal structure was eliminated (Photo 9c).

\section{Monitoring the regeneration of $P$. platyphylla leaf cells after 5- month cold, subsequent 1-day desiccation and rewetting}

After a 5-month cold in the dark (at $5^{\circ} \mathrm{C}$ ), P. platyphylla leafs were desiccated for 1 day. 0,10, 30, 40 minutes, 1, 24, and 48 hours after rehydration the regeneration of the cell structure was monitored by light microscopy. During the regeneration process a kind of trend could be observed. After 30 minutes, in the initial rewetting phase the cells were plasmolyzed softly and oil bodies started to be flattened (Photo 10a). 24 hours after the rewetting chloroplasts had a round shape instead of elliptical, oil bodies had a calyx form instead of a spindle shape (Photo 10b). 48 hours after rehydration chloroplasts completed their regeneration, oil bodies were seen as spectacularly big, shiny spherical organelles (Photo 10b).

24 hours after the rewetting is a critical point in the regeneration. Presumably, if the constitutive and inductive protection mechanisms are properly coordinated, the cell structure is capable of complete regeneration after the still tolerable stress effect they suffered, as can be seen by light microscopy. 

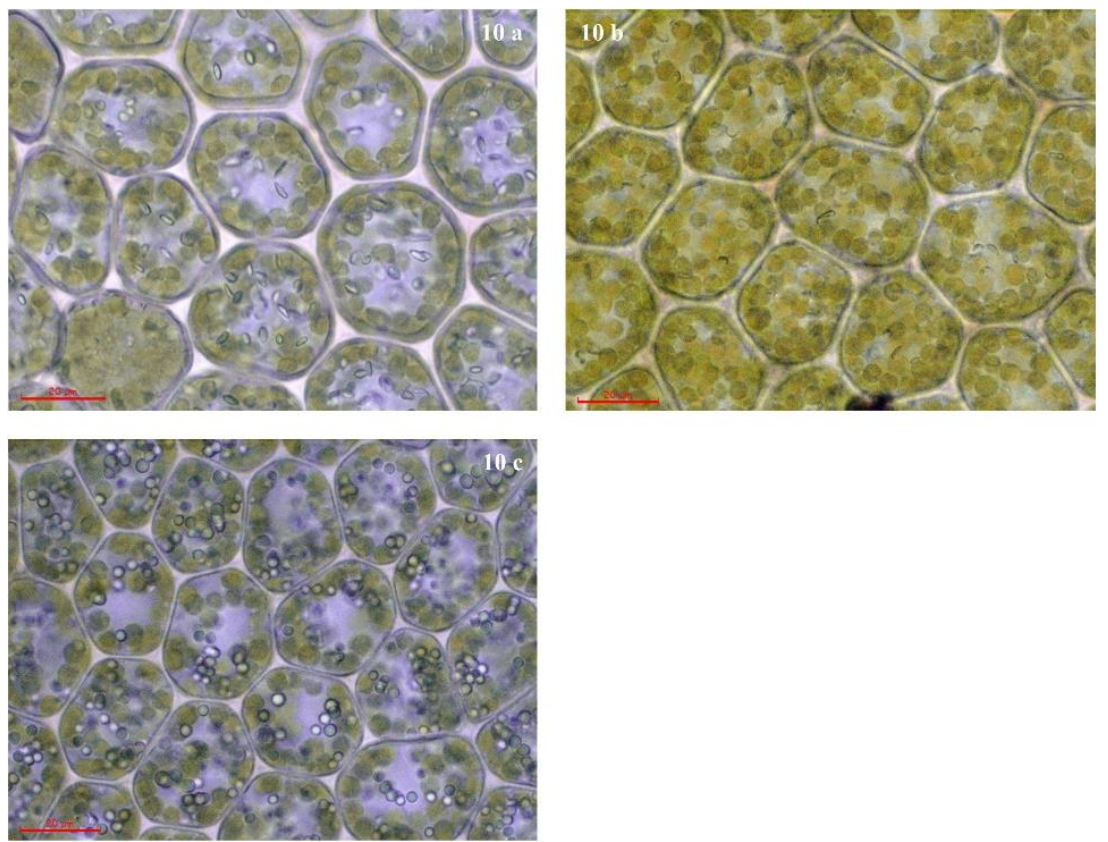

Photo 10a, b, c. Monitoring the regeneration of $P$. platyphylla leaf cells after 5month cold, subsequent 1-day drying and rewetting. The leaf cells of $P$. platyphylla following rehydration after a) $30 \mathrm{~min}$, b) 24 hours, c) 48 hours. Scale bars $=2 \mu \mathrm{m}$.

\section{Osmotic stress applied by KSCN- and PEG-treatments}

The $1 \mathrm{M} \mathrm{KSCN}$-treatment (which represented a $-4.38 \mathrm{MPa}$-strength osmotic stress to the cells) resulted in the most drastic effect in the shortest time. The cells began to be damaged after 10 minutes. The central vacuoles fragmented into smaller ones and then they disintegrated (Photo 11a, $b, 12 a, b$ ). At the same time an irreversible destruction of chloroplasts began. The oil bodies started to become damaged only 1 hour after the treatment. So, the oil bodies proved to be the most resistant organelle against various stress factors. 0.5 $\mathrm{M} \mathrm{NaCl}$-treatment due to its -2.32 MPa-strength osmotic stress effect had the same influence on the cell structure as $1 \mathrm{M} \mathrm{KSCN} \mathrm{did,} \mathrm{but}$ after 40 minutes.

The 25\% PEG does not penetrate into the cells, only develop higher osmotic pressure in the intercellular space. The osmotic effect of the 25\% PEG developed later than the effect of the $1 \mathrm{M}$ KSCN, due to the milder osmotic effect of the 25\% PEG (-1.435 MPa), but the process of the plasmolysis was similar, the oil bodies 
remained intact the longest and the vacuole membrane was damaged first in the two-hundredth minute (Photo 13a, b). The $25 \%$ PEG resulted in its maximal effect, total plasmolysis, in Allium cepa leaves within 5 minutes.
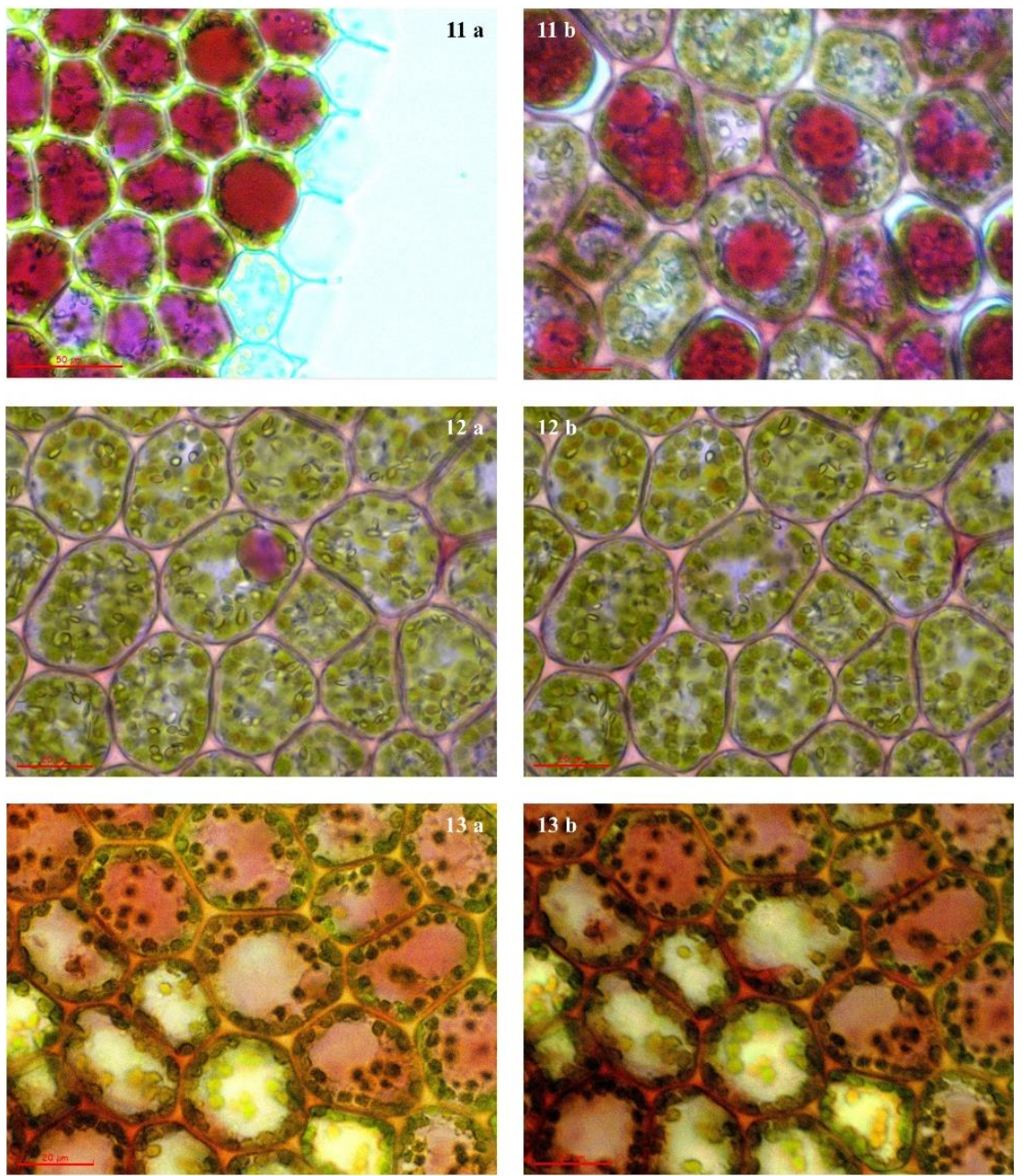

Photo 11a, b. The effect of $1 \mathrm{M}$ KSCN-treatment after a) 0 minute, b) 10 minutes on the fully turgid leaf cells of P. platyphylla stained with neutral red at $\mathrm{pH}$ 7.6. Scale bars $=2 \mu \mathrm{m}$. Photo 12a, b. The effect of $1 \mathrm{M}$ KSCN-treatment after a) 11 minutes, b) 12 minutes on the fully turgid leaf cells of $P$. platyphylla stained with neutral red at pH 7.6. Scale bars $=2 \mu \mathrm{m}$. Photo 13a, b. The effect of 25\% PEG-treatment after a) 200 minutes, b) 201 minutes on the fully turgid leaf cells of $P$. platyphylla stained with neutral red at pH 7.6. Scale bars $=2 \mu \mathrm{m}$. 


\section{CONCLUSIONS}

The leaf cells of the extremely desiccation tolerant leafy liverwort, $P$. platyphylla contain lots of oval chloroplasts and shiny homogeneous oil bodies are visible in turgid cells. Oil bodies in P. platyphylla are small, massula type, homogenous, simple, round, 1-2 $\mu \mathrm{m}$ size, numerous, and not very distinct. Like many other DT liverworts, $P$. platyphylla is extremely difficult to infiltrate with resin (Duckett et al. 1988), the improminent oil bodies do not fix and embed well for electron microscopy (Duckett et al. 2006a, 2006b). The leaf cells of this liverwort due to their one-cell layered structure can be studied natively by light microscope. In the lack of a good electron microscopic embedding technique, views we get by light microscopy from this liverwort could be important and valuable.

We monitored the effects of various abiotic stress factors at cell level following the rate of plasmolysis, and the changes in the structure of cell organelles (chloroplasts, vacuoles, oil bodies). Furthermore our aim was to test the applicability of different stains (neutral red, toluidine blue, methylene blue, Sudan-III) in Porella platyphylla cells under experimental treatments. Natural drying at room temperature (for 1 day, 1 week, '62 years' by checking an old herbarium sample), subsequent rehydration, freezing at -18 and $-80^{\circ} \mathrm{C}$, heat treatment at 40,50 and $100^{\circ} \mathrm{C}$ (for 5 and $10 \mathrm{~min}$ ), osmotic and salt stress (0.5 M NaCl, $1 \mathrm{M} \mathrm{KSCN}, 25 \%$ PEG8000) were applied. In the course of monitoring the various stress factors the use of neutral red (at $\mathrm{pH}$ 7.6) staining proved to be the most optimal. In control plants one big cherry coloured vacuole could be discovered after staining. The central vacuole fragmented into small pieces, then ruptured after 10 minutes due to the strongest osmotic treatment (1 M KSCN). At the same time chloroplasts were irreversibly disrupted. The oil bodies proved to be the most resistant structures against the various stress factors. The freezing at $-18^{\circ} \mathrm{C}$ resulted in more visible damage symptomes in the cell structure than freezing at $-80^{\circ} \mathrm{C}$. In the 62-year-old herbarium tissue it was easy to monitor the desiccation effect as the whole membrane structure was damaged.

Plants hardened for 5-month long cold were able to regenerate their cell structure and metabolism within 48 hours after 1-day natural desiccation. During the regeneration process the following cell structural changes could be observed after 30 minutes, in the initial rewetting phase the cells were plasmolyzed softly and oil 
bodies started to be flattened (Photo 11a). 24 hours after the rewetting chloroplasts had a round shape instead of elliptical, oil bodies has a calyx form instead of a spindle shape (Photo 11b). 48 hours after rehydration chloroplasts completed their regeneration, oil bodies were seen as spectacularly big, shiny spherical organelles.

The 24 hours after the rewetting is found to be a critical point in the regeneration process. Presumably, if the constitutive and inductive protection mechanisms are properly coordinated, the cell structure is capable of complete regeneration after the still tolerable stress effect they suffered, as can be seen by light microscopy.

The 3 different high temperature treatments $\left(40,50,100^{\circ} \mathrm{C}\right)$ resulted in similar changes in the cell structure to those affected by the two freezing treatments. Tissues were coloured by neutral red before freezing and heat treatments suffered less injury compared with the unstained ones. Light microscopic studies are convenient to monitor the regeneration of the cell structure after stress. Our findings are in line with other authors' work concerning other liverwort species in that the oil bodies, while retaining their original volume during drying, collapse during rehydration (Pressel et al. 2009). Marschall et al. (1998) and this work also suggest a shifting of soluble carbohydrates or other moieties into the cytosol and provides more experimental evidence that the oil bodies may have a crucial role in desiccation tolerance. Major subcellular changes in mosses, Selaginella lepidophylla (Platt et al. 1994), and some DT angiosperms (Dalla Vecchia et al. 1998; Navari-Izzo et al. 2000) include fragmentation of the vacuole and rounding of the chloroplasts (Li et al. 2014) and mitochondria, with the thylakoids and cristae remaining undamaged during the regeneration after desiccation or osmotic stress. The cell structure and its changes in the $P$. platyphylla during the various stress experiments give a good explanation of the stress tolerance of the species under natural circumstances.

Acknowledgement - The authors are grateful to Albert Vermes for reading and correcting the English language of the manuscript and also for the financial support of the EMMI 2015/16 researcher fellowship.

\section{REFERENCES}

Asakawa, Y. (1995). Chemical constituents of the bryophytes. Progress in the chemistry of organic natural products. Vol 65. Springer, Vienna. 615 pp. 
Chalaud, G. (1931). Germination des sporeset formation du gametophyte chez Lophocolea cuspidata et Chiloscyphus polyanthus. Annales of Bryology 4: 49-78.

Dalla Vecchia, F., Asmar, T.E., Calamassi, R., Rascio, N. \& Vazzana, C. (1998). Morphological and ultrastructural aspects of dehydration and rehydration in leaves of Sporobolus stapfianus. Plant Growth Regulation 24(3): 219-228.

DuCKETT, J.G. (1986). Ultrastructure in bryophyte systematics and evolution: an evaluation. Journal of Bryology 14: 25-42.

Duckett, J.G., CARAFA, A. \& Ligrone, R. (2006a). A highly differentiated glomeromycotean association with the mucilage-secreting, primitive antipodean liverwort Treubia (Treubiaceae): clues to the origins of mycorrhizas. American Journal of Botany 93(6): 797-813.

DuCKETT, J.G. \& CLYMo, R.S. (1988). Regeneration of bog liverworts. New Phytologist 110(1): 119-127.

DucketT, J.G. \& Ligrone, R. (1995). The formation of catenate foliar gemmae and the origin of oil bodies in the liverwort Odontoschisma denudatum (Mart). Dum. (Jungermanniales): a light and electron microscope study. Annals of Botany 76: 405-419.

Duckett, J.G., Russel, J. \& Ligrone, R. (2006b). Basidiomycetous endophytes in jungermannialean (leafy) liverworts have novel cytology and species-specific host ranges: a cytological and experimental study. Canadian Journal of Botany 84(7): 1075-1093.

Galatis, B., Apostolakos, P. \& Katsaros, C. (1978). Ultrastructural studies on the oil bodies of Marchantia paleacea Bert. I. Early stages of oil-body cell differentiation: origination of the oil body. Canadian Journal of Botany 56: 22682285.

GavaudAn, P. (1927). Sur l'origine et les charactéres des éléments oliféres des Jungermanniales. C.R. Acad. Sci. 184: 1473-1475.

HE, X., Sun, Y. \& ZHU, R. (2013). The Oil Bodies of Liverworts: Unique and Important Organelles in Land Plants. Critical Reviews in Plant Sciences 32: 293-302.

He-Nygrén, X., Juslén, A., Ahonen, I., Glenny, D. \& PiIPpo, S. (2004). Phylogeny of liverworts - beyond a leaf and a thallus. Monographs in Systematic Botany from the Missouri Botanical Garden 98: 87-118.

Hieronymus, G. (1892). Beitrage zur Morphologie und Biologie der Algen. Beiträge zur Biologie der Pflanzen 5: 461-495.

KenRick, P. \& Crane, P.R. (1997). The origin and early evolution of land plants. Nature 389: 33-39.

KIs, G. \& Pócs, T. (1997). Oil body studies on African Hepaticae. Journal of the Hattori Botanical Laboratory 81: 175-242.

LI, J., Li, X. \& ChEn, C. (2014). Degradation and reorganization of thylakoid protein complexes of Bryum argenteum in response to dehydration and rehydration. The Bryologist 117(2): 110-118.

MarsChall, M., Proctor, M.C.F. \& SMirnofF, N. (1998). Carbohydrate composition and invertase activity of the leafy liverwort Porella platyphylla. New Phytologist 138: 343-353.

Marschall, M. \& Proctor, M.C.F. (1999). Desiccation tolerance and recovery of the leafy liverwort Porella platyphylla (L.) Pfeiff.: chlorophyll-fluorescence measurements. Journal of Bryology 21: 257-262. 
MÜlLER, K. (1906). Die Lebermoose. Pages 65-128 in: Rabenhorst's KryptogamenFlora von Deutschland, Oesterreich, und der Schweiz. 2nd ed. Vol 6. Leipzig, E. Kummer.

Navari-Izzo, F., Quartacci, M.F., Pinzino, C., Rascio, N., Vazzana, C. \& Sgherri, C.L.M. (2000). Protein Dynamics in Thylakoids of the Desiccation-Tolerant Plant Boea hygroscopica during Dehydration and Rehydration. Plant Physiology 124(3):1427-1436.

Paton, J.A. (1999). The liverwort flora of the British Isles. Harley, Colchester, England, $626 \mathrm{pp}$.

Platt, K.A., Oliver, M.J. \& Thomson, W.W. (1994). Membranes and organelles of dehydrated Selaginella and Tortula retain their normal configuration and structural integrity: freeze fracture evidence. Protoplasma 178(1): 57-65.

Pressel, S., Duckett, J.G., Ligrone, R. \& Proctor, M.C.F. (2009). Effects of de- and rehydration in desiccation-tolerant liverworts: A cytological and physiological study. International Journal of Plant Sciences 170(2): 182-199.

Pressel, S., L Ligrone \& DucketT, J. G. (2006). Effects of de-and rehydration on foodconducting cells in the moss Polytrichum formosum. Hedw.: a cytological study. Annals of Botany 98: 67-76.

Proctor, M.C.F., Ligrone, L. \& DucketT, J. G. 2007(a). Desication tolerance in the moss Polytrichum formosum: physiological and fine-structural changes during dessication and recovery. Annals of Botany 99: 75-93.

Proctor, M.C.F., Oliver, M.J., Wood, A.J., AlPert, P., Stark, L.R., CleavitT, N.L. \& Mishler, B.D. 2007(b). Desiccation-tolerance in bryophytes: a review. The Bryologist 110(4): 595-621.

Qui, Y.L., Li, L., Wang, B., Chen, Z., Knoop, V., Groth-Malonek, M., Dombrovska, O., LeE, J., Kent, L., Rest, J., Estabrook, G.F., Hendry, T.A., Taylor, D.W., Testa, C.M., Ambros, M., Crandall-Stotler, B., Duff, R.J., Stech, M., Frey, W., Quandt, D. \& Davis C.C. (2006). The deepest divergence in land plants inferred from phylogenetic evidence. PNAS 17: 15511-15516.

Rubinstein, C.V., Gerrienne, P., De la Puente, G.S., Astini, R.A. \& Steemans, P. (2010). Early Middle Ordovician evidence for land plants in Argentina (eastern Gondwana). New Phytologist 188: 365-369.

SASs-Gyarmati, A. (2015). Taxonomical revision of Lopholejeunea (Spruce) Schiffn. (Lejeuneaceae, Hepaticae) in Africa (in Hungarian). PhD Dissertation, Szent István University, Gödöllő, 109 pp.

SmiRnoff, N. (1992). The carbohydrates of bryophytes in relation to desiccation tolerance. Journal of Bryology 17: 185-191.

StEwART, G.H. (1978). Oil bodies of the New Zealand leafy Hepaticae (Jungermanniales). New Zealand Journal of Botany 16: 185-205.

SuiRe, C. (1975). Les données actuelles sur la chimie des Bryophytes. Review of Bryology and Lichenology 41: 105-256.

Suire, C., Bouvier, F., Backhaus, R.A., BÉGu, D., Bonneu, M. \& CAmara, B. (2000). Cellular localization of isoprenoid biosyntethic enzymes in Marchantia polymorpha. Uncovering a new role of oil bodies. Plant Physiology 124: 971-978.

WELLMAN, C.H., OSTERLOFF, P.L. \& MoHLUdDin, U. (2003). Fragments of the earliest land plants. Nature 425: 282-284.

(submitted: 09.08.2016, accepted: 22.10.2016) 